\title{
Meta-analysis of effects of age on intestinal digestibility of liquid feeds in young calves
}

\author{
J. D. Quigley,* $\odot$ T. S. Dennis, ๑ F. X. Suarez-Mena, ๑T. M. Hill, $\odot$ and K. M. Aragona $\odot$
}

\section{Graphical Abstract}
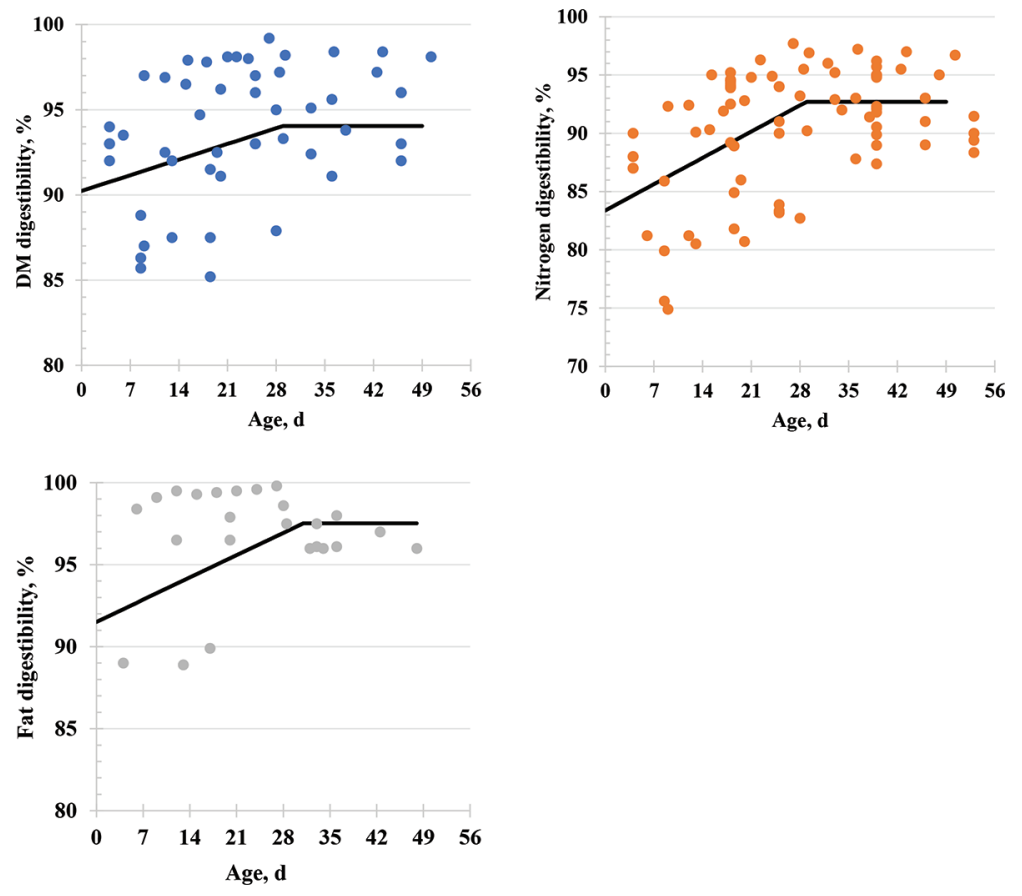

\section{Summary}

Intestinal digestibility of nutrients in milk and milk replacer is immature at birth but increases with advancing age. We showed that digestibility of dry matter, nitrogen, and fat increased to approximately 30 days of age.

\section{Highlights}

- Intestinal digestibility of nutrients in milk and milk replacer is immature in young calves.

- Digestibility increases with advancing age and maturation of the gastrointestinal tract.

- Digestibility of dry matter, nitrogen, and fat increased to approximately 30 days of age, after which no further improvement was observed.

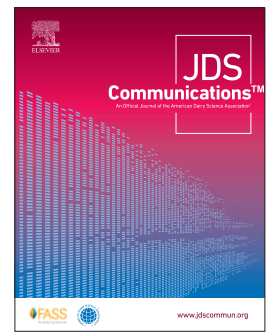

Nurture Research Center, Provimi North America, Cargill Animal Nutrition, Brookville, OH 45309. *Corresponding author: jquigley@provimi-na.com. @ 2021, The Authors. Published by Elsevier Inc. and Fass Inc. on behalf of the American Dairy Science Association ${ }^{\circledast}$. This is an open access article under the CC BY license (http://creativecommons.org/licenses/by/4.0/). Received November 23, 2020. Accepted January 23, 2021. 


\title{
Meta-analysis of effects of age on intestinal digestibility of liquid feeds in young calves
}

\author{
J. D. Quigley, ${ }^{*} \odot$ T. S. Dennis, $\odot$ F. X. Suarez-Mena, $\odot$ T. M. Hill, $\odot$ and K. M. Aragona $\odot$
}

Abstract: A meta-analysis was conducted to determine the effect of age on digestibility of liquid feeds fed to preweaned Holstein calves. Calves were 4 to $76 \mathrm{~d}$ of age and fed whole milk or milk replacer containing all-milk protein. Least squares means of apparent total-tract N, DM, and fat digestibilities ( $\mathrm{n}=84,51$, and 24, respectively) from 12 publications were used. Broken line regression and mixed model ANOVA were used to determine ages at which digestion of nutrients no longer increased with age, indicating maturation of digestive capacity. Digestibility of DM, N, and fat reached maximum digestibilities of 94.1, 92.7, and 97.5\% at 29, 29, and 32 d of age, respectively. These data indicate age-related changes in digestion of liquid feeds in preweaned Holstein calves and allow correction of apparent total-tract digestibility estimates in nutrient supply models. Digestibility of liquid nutrients in calves fed whole milk or all milk containing milk replacers reached maximal capacity at approximately $30 \mathrm{~d}$ of age.

iquid feeds fed to calves before weaning are normally shunted Lpast the reticulorumen via nervous closure of the esophageal groove, thereby avoiding ruminal fermentation of nutrients. Therefore, the maturity of gastric and intestinal digestion determines nutrient digestibility of these feeds. Numerous studies have documented effects of age on digestibility of nutrients in liquid feed for preweaned dairy calves. For example, Terosky et al. (1997) reported that $\mathrm{N}$ digestibility in calves fed milk replacers containing whey or skim milk proteins increased from approximately $70 \%$ to $90 \%$ from 2 to 8 wk of age. Others reported similar increases with advancing age, generally concluding that digestibility increases to approximately 3 wk (Arieli et al., 1995; Terosky et al., 1997; NRC, 2001) or 5 wk (Guilloteau et al., 2009) of age. Total nutrient digestibility and rate of change in nutrient digestibility with advancing age may also vary with ingredients in the feed, as non-milk proteins are digested differently than milk proteins (e.g., Branco-Pardal et al., 1995; Thornsberry et al., 2016). Also, fat digestibility is affect- ed by fat source (Radostits and Bell, 1968; Johnson and Leibholz, 1980) and method of processing and emulsification (Hopkins et al., 1959; Jenkins et al., 1981).

Nutrient supply models generally ignore the maturation of intestinal digestibility with advancing age (e.g., NRC, 2001). Unfortunately, few published data document changes in digestibility with advancing age or protein source. Therefore, the objective of this research was to develop a model of changing nutrient digestibility of liquid feeds in calves to weaning.

Published research studies that measured apparent total-tract digestibility of nutrients of milk or milk replacer in preweaned Holstein calves were identified (Table 1). The initial literature search was conducted using Google Scholar and PubMed using the search terms "calf," "calves," "digestion," "digestibility," "milk," and "milk replacer." Criteria for inclusion were measurement of apparent total-tract digestibility of DM, N, or fat in Holstein calves fed whole milk or milk replacer on at least 2 measurement peri-

Table 1. Raw means from studies comprising the data used in model development

\begin{tabular}{|c|c|c|c|c|c|c|}
\hline \multirow[b]{2}{*}{ Reference } & \multirow[b]{2}{*}{ No. ${ }^{1}$} & \multirow[b]{2}{*}{ Type } & \multirow[b]{2}{*}{ Age, d } & \multicolumn{3}{|c|}{ Digestibility } \\
\hline & & & & $\mathrm{N}, \%$ & DM, \% & Fat, \% \\
\hline Noller et al., 1956 & 7 & Milk & $12-36$ & $81-93$ & $88-96$ & $97-99$ \\
\hline Wood et al., 1970 & 6 & Milk & 9-19 & $80-89$ & $85-92$ & \\
\hline Volcani et al., 1971 & 2 & Milk & $34-48$ & $92-95$ & & 96 \\
\hline Bouchard et al., 1973 & 4 & Skim & $9-38$ & $75-92$ & $87-94$ & \\
\hline Toullec et al., 1974 & 4 & Milk & $17-76$ & $92-96$ & $95-97$ & $89-97$ \\
\hline Donnelly and Hutton, 1976 & 18 & Milk & 18 and 39 & $89-96$ & & \\
\hline Neergaard, 1979 & 6 & Milk & $15-50$ & $98-98$ & & \\
\hline Russell et al., 1980 & 8 & Milk & $6-27$ & $81-98$ & 94-99 & $98-99$ \\
\hline Akinyele and Harshbarger, 1983 & 4 & Milk & $10-33$ & $90-95$ & $88-95$ & $89-98$ \\
\hline Stobo, 1983 & 12 & Skim & 4-46 & $87-94$ & $92-97$ & \\
\hline Terosky et al., 1997 & 11 & Skim/WPC ${ }^{2}$ & $25-53$ & 77-92 & & \\
\hline Guilloteau et al., 2009 & 2 & Skim & 4 and 32 & $87-96$ & & $89-96$ \\
\hline Total or range & 84 & & $4-76$ & $75-98$ & $85-99$ & 89-99 \\
\hline
\end{tabular}

${ }^{1}$ Number of least squares means per study.

${ }^{2}$ Whey protein concentrate. 
ods. Trials were excluded if significant dry feed was consumed or when novel ingredients or non-milk proteins were included in milk replacer treatments. Treatments in which calves were reported to have experienced diarrhea were also excluded.

A broken-line regression approach (Robbins et al., 2006) was used to analyze the data, assuming that digestibilities increased to a point of relative maturity within the ages included in the database. The NLMIXED procedure of SAS (version 8; SAS Institute Inc.) was used. Random component for asymptote was included in each analysis, and treatment within study was included in the random statement as subject.

Following determination of age at which maximal nutrient digestion was achieved, the data set was limited to measurements $\leq 30 \mathrm{~d}$ and was subsequently modeled using the mixed modeling approach described by St-Pierre (2001). The model was nutrient digestibility $(\%)=$ age (days); intercept and age were included as random components, and treatment was included as subject.

Digestibility data were available from 12 studies, with 30 unique treatments and a total of 84,51 , and 24 observations for N, DM, and fat digestibilities, respectively (Table 1). Age of calf ranged from 4 to $76 \mathrm{~d}$, and digestibilities of N, DM, and fat ranged from 75 to 98,85 to 99 , and 89 to $99 \%$, respectively.

Results of broken-line regression and mixed model analyses are in Table 2. For the broken-line regressions, asymptotes for DM, N, and fat were 94.1, 92.7, and 97.5\%, respectively. Ages at which mature digestion was reached were 29,29 , and $32 \mathrm{~d}$, respectively. Broken-line regressions for N, DM, and fat digestibility are in Figure 1.

Mixed model linear regression coefficients (Table 2) for digestibilities to $30 \mathrm{~d}$ of age were similar to calculations for broken-line regression. The coefficients of determination were calculated by linear regression of adjusted data on age (St-Pierre, 2001). The intercepts for fat and total DM were greater than $90 \%$, and the intercept for $\mathrm{N}$ digestibility was $83 \%$. Slopes indicated relative rate of digestive maturation from 4 to $30 \mathrm{~d}$ of age. Graphical representations of the change in nutrient digestibility from 1 to $30 \mathrm{~d}$ of age for DM, N, and fat are shown in Figure 1D, E, and F, respectively.

Knowledge of changing nutrient digestibility with maturation of the gastrointestinal tract in young calves is essential to accurate formulation of diets to meet nutrient requirements. Numerous studies have documented changing digestion of nutrients with advancing age (Noller et al., 1956; Terosky et al., 1997; Guilloteau et al., 2009), though others have reported no significant change in digestibility of fat or $\mathrm{N}$ between 8 and $28 \mathrm{~d}$ (Strudsholm, 1988). Changes in enzymatic activities and gastric and pancreatic secretions responsible for changing nutrient digestibility in the first month of life have been reviewed (Ruckebusch et al., 1983; Thornsberry et al., 2016).

Digestibility of DM increased from $90 \%$ at d 4 to $94 \%$ on d 30 with no increase in digestibility thereafter. Apparent DM digestibility of milk and calf milk replacer has been reported to be approximately 95\% (Branco-Pardal et al., 1995) in calves older than $30 \mathrm{~d}$ of age, which is similar to the asymptote value of $94 \%$.

Estimated digestibility of $\mathrm{N}$ for whole milk and all-milk-protein calf milk replacer ranged from $83 \%$ at $1 \mathrm{~d}$ of age to $93 \%$ at $29 \mathrm{~d}$ of age. The value of $93 \% \mathrm{~N}$ digestibility is identical to the estimate used by NRC (2001) to calculate apparent digestible protein from CP.

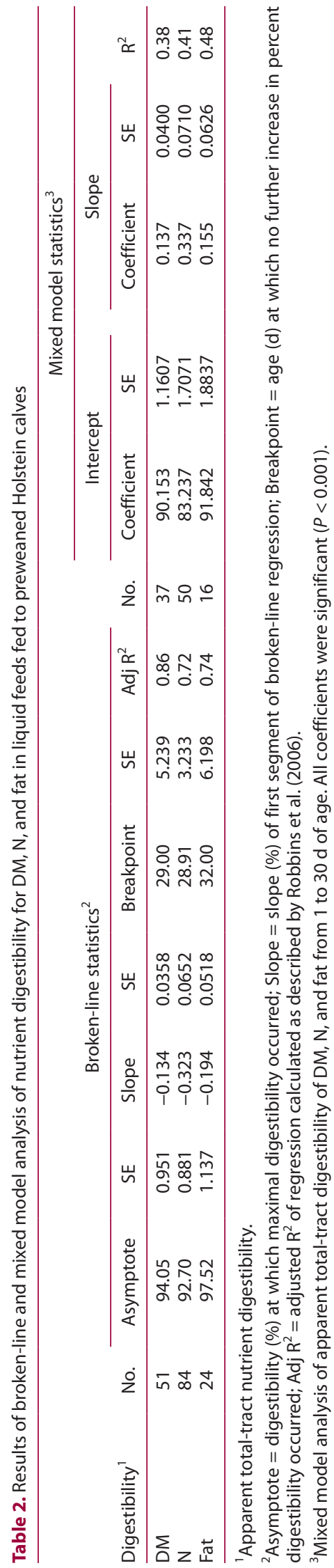


Digestibilities of $\mathrm{N}$ early in life were lower as a proportion of mature $\mathrm{N}$ digestibility, which may be related to the relative immaturity of the gastrointestinal tract and pancreatic secretions (Guilloteau et al., 2009). However, the rate of increase of $\mathrm{N}$ digestibility with age was greater than that for other nutrients, suggesting that maturation of protein digestion is rapid. Liang et al. (2016) reported that $\mathrm{N}$ digestibility in Jersey calves fed $11.6 \mathrm{~g} / \mathrm{kg}$ of BW of a $20 \% \mathrm{CP}, 20 \%$ fat milk replacer containing all milk protein increased from $80.7 \%$ at 1 to $3 \mathrm{~d}$ of age to $86.7 \%$ at 4 to $7 \mathrm{~d}$ of age.
Conversely, $\mathrm{N}$ digestibility did not change with age when calves were fed $19.2 \mathrm{~g} / \mathrm{kg}$ of BW of a $28 \%$ protein, $20 \%$ fat milk replacer ( 90.1 and $87.1 \% \mathrm{~N}$ digestibility during 1 to 3 and 4 to $7 \mathrm{~d}$ of age, respectively). Similarly, Quigley et al. (2019) recently reported no significant increase in protein digestibility from 1 to 3 wk of age when calves were fed 0.66 or $0.77 \mathrm{~kg} / \mathrm{d}$ of milk replacer; however, protein digestibility values were generally low (83-88\%) during the trial.
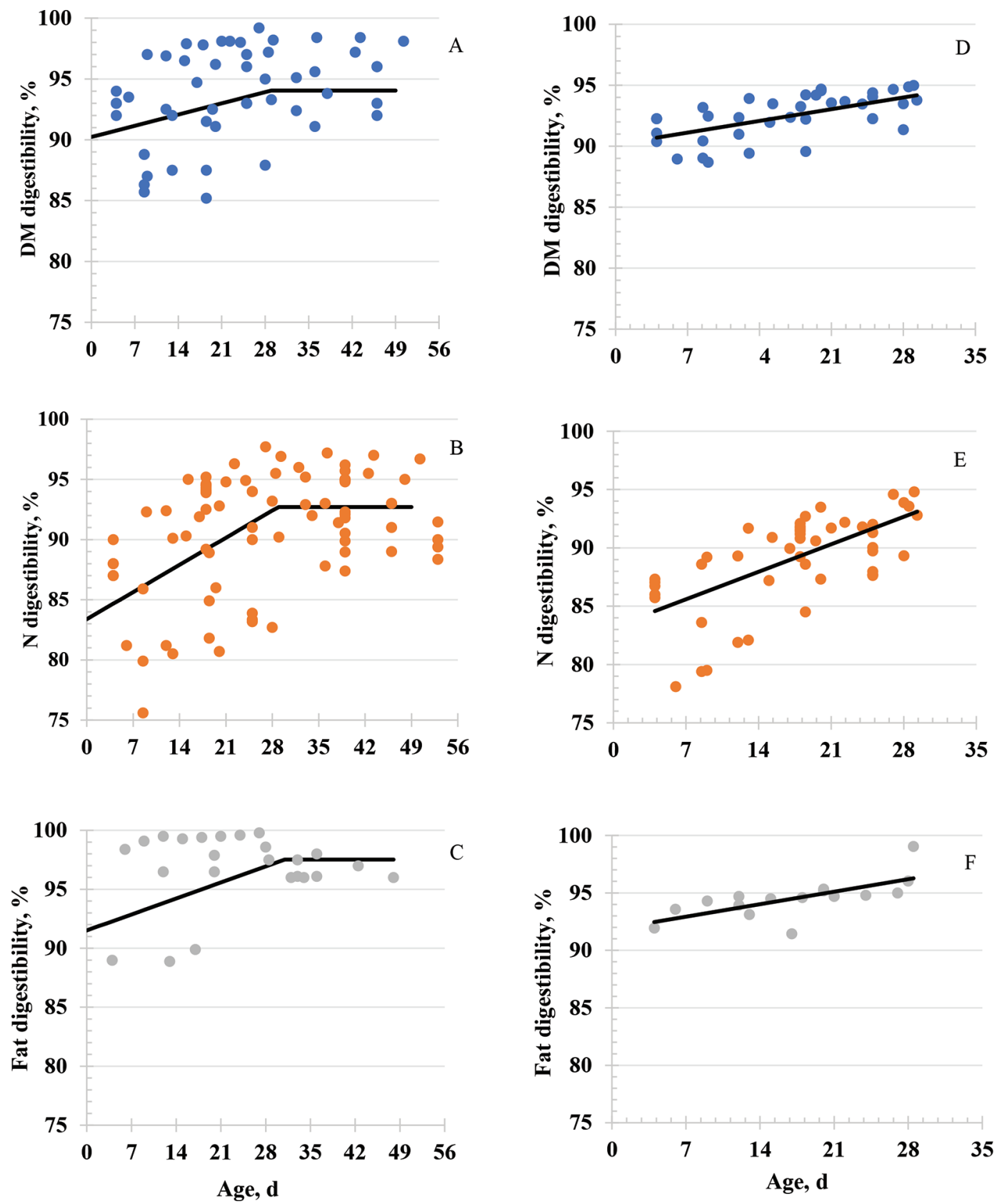

Figure 1. Broken-line mixed model analyses for DM (A), N (B), and fat (C), and mixed model linear regression to $30 \mathrm{~d}$ of age for DM (D), N (E), and fat (F) apparent total-tract digestibility in Holstein calves fed liquid feeds containing all milk. Mixed model regression observations are adjusted means as described by St-Pierre (2001). 
Only 6 studies reported apparent total-tract fat digestibility that met all criteria for inclusion in the metanalysis. Digestion of fat increased with increasing age to approximately $32 \mathrm{~d}$ (Figure 1C) to maximum apparent total-tract digestibility of $97.5 \%$ (Table 2). However, 3 least squares means $\leq 90 \%$ appeared to influence the regression (Figure 1C). Increasing production of pancreatic lipase in the first month of life may contribute to increasing digestibility of lipid by the milk-fed calf (Guilloteau et al., 2009). Use of emulsifiers and processing technology has also improved digestibility of lipids in commercial milk replacer formulas (Thornsberry et al., 2016). On the other hand, Quigley et al. (2019) recently reported that fat digestibility averaged $96 \%$ at $1 \mathrm{wk}$ of age when calves were fed high-quality commercial milk replacer containing lard as the primary fat source.

Broken-line regression indicated that digestive maturity occurred at 29, 29, and $32 \mathrm{~d}$ of age for DM, N, and fat, respectively. A mixed model approach was also used for data from 1 to $30 \mathrm{~d}$ of age (Table 2; Figure 1D, E, and F). Results were similar to those for broken-line regressions.

Changing digestion of nutrients during the first month of life influences total nutrient supply to the animal and can influence growth. Often, models of nutrient supply overestimate growth of calves during the first month of life, which may be related to overestimated supply of energy and protein. Adjusting digestibility of liquid feeds using the equations developed herein may improve prediction of nutrient supply and estimates of growth in young calves.

\section{References}

Akinyele, I. O., and K. E. Harshbarger. 1983. Performance of young calves fed soybean protein replacers. J. Dairy Sci. 66:825-832. https://doi.org/10 .3168/jds.S0022-0302(83)81863-3.

Arieli, A., J. W. Schrama, W. Van Der Hel, and M. W. A. Verstegen. 1995. Development of metabolic partitioning of energy in young calves. J. Dairy Sci. 78:1154-1162. https://doi.org/10.3168/jds.S0022-0302(95)76732-7.

Bouchard, R., G. J. Brisson, and J. P. Julien. 1973. Nutritive value of bacterial sludge and whey powders for protein in calf milk replacers and on chromic oxide as indicator of digestibility. J. Dairy Sci. 56:1445-1449. https://doi .org/10.3168/jds.S0022-0302(73)85381-0.

Branco-Pardal, P., J. P. Lallès, M. Formal, P. Guilloteau, and R. Toullec. 1995. Digestion of wheat gluten and potato protein by the preruminant calf: Digestibility, amino acid composition and immunoreactive proteins in ileal digesta. Reprod. Nutr. Dev. 35:639-654. https://doi.org/10.1051/rnd: 19950604.

Donnelly, P. E., and J. B. Hutton. 1976. Effects of dietary protein and energy on the growth of Friesian bull calves. I. Food intake, growth, and protein requirements. N. Z. J. Agric. Res. 19:289-297. https://doi.org/10.1080/ 00288233.1976.10429068.

Guilloteau, P., R. Zabielski, and J. W. Blum. 2009. Gastrointestinal tract and digestion in the young ruminant: Ontogenesis, adaptations, consequences and manipulations. J. Physiol. Pharmacol. 60(Suppl. 3):37-46.

Hopkins, D. T., R. G. Warner, and J. K. Loosli. 1959. Fat digestibility by dairy calves. J. Dairy Sci. 42:1815-1820. https://doi.org/10.3168/jds.S0022 -0302(59)90813-6.

Jenkins, K. J., J. K. G. Kramer, and D. B. Emmons. 1981. Digestion of fat in calves fed milk replacers prepared by homogenization or low-pressure dispersion. J. Dairy Sci. 64:1965-1971. https://doi.org/10.3168/jds.s0022 $-0302(81) 82798-1$.

Johnson, R., and J. Leibholz. 1980. Influence of the type of fat in milk replacers on hydrolysis and digestion by the pre-ruminant calf. J. Sci. Food Agric. 31:162-170. https://doi.org/10.1002/jsfa.2740310207.
Liang, Y., J. A. Carroll, and M. A. Ballou. 2016. The digestive system of 1 -week-old Jersey calves is well suited to digest, absorb, and incorporate protein and energy into tissue growth even when calves are fed a high plane of milk replacer. J. Dairy Sci. 99:1929-1937. https://doi.org/10.3168/jds .2015-9895.

Neergaard, L. 1979. Influence of specially extracted soya meal on nitrogen and energy metabolism in the preruminant calf. Pages 43-47 in Energy Metabolism: Proceedings of the Eighth Symposium on Energy Metabolism. L. E. Mount, ed. EAAP Publication No. 26. Butterworths.

Noller, C. H., G. M. Ward, A. D. McGilliard, C. F. Huffman, and C. W. Duncan. 1956. The effect of age of the calf on the availability of nutrients in vegetable milk replacer rations. J. Dairy Sci. 39:1288-1298. https://doi.org/10 .3168/jds.S0022-0302(56)94847-0.

NRC. 2001. Nutrient Requirements of Dairy Cattle. 7th rev. ed. National Academies Press.

Quigley, J. D., L. Deikun, T. M. Hill, F. X. Suarez-Mena, T. S. Dennis, and W. Hu. 2019. Effects of colostrum and milk replacer feeding rates on intake, growth, and digestibility in calves. J. Dairy Sci. 102:11016-11025. https:// doi.org/10.3168/jds.2019-16682.

Radostits, O. M., and J. M. Bell. 1968. Nutrient digestibility by new-born calves fed milk replacer. Can. J. Anim. Sci. 48:293-302. https://doi.org/ 10.4141/cjas68-040.

Robbins, K. R., A. M. Saxton, and L. L. Southern. 2006. Estimation of nutrient requirements using broken-line regression analysis. J. Anim. Sci. 84(E. Suppl.):E155-E165. https://doi.org/10.2527/2006.8413_supp1E155x.

Ruckebusch, Y., C. Dardillat, and P. Guilloteau. 1983. Development of digestive functions in the newborn ruminant. Ann. Rech. Vet. 14:360-374.

Russell, R. W., V. Caruolo, and G. H. Wise. 1980. Effects of pregastric esterase on utilization of whole milk by preruminant calves. J. Dairy Sci. 63:1114-1122. https://doi.org/10.3168/jds.S0022-0302(80)83055-4.

St-Pierre, N. R. 2001. Invited review: Integrating quantitative findings from multiple studies using mixed model methodology. J. Dairy Sci. 84:741755. https://doi.org/10.3168/jds.S0022-0302(01)74530-4.

Stobo, I. J. F. 1983. Milk replacers for calves. Pages 113-140 in Recent Advances in Animal Nutrition. W. Haresign, ed. Butterworths.

Strudsholm, F. 1988. The effect of curd formation in the abomasum on the digestion of milk replacers in preruminant calves. Acta Agric. Scand. 38:321-327. https://doi.org/10.1080/00015128809437994.

Terosky, T. L., A. J. Heinrichs, and L. L. Wilson. 1997. A comparison of milk protein sources in diets of calves up to eight weeks of age. J. Dairy Sci. 80:2977-2983. https://doi.org/10.3168/jds.S0022-0302(97)76264-7.

Thornsberry, R. M., D. Wood, A. F. Kertz, and D. Hutcheson. 2016. Alternative ingredients in calf milk replacer-A review for bovine practitioners. Bov. Pract. 50:65-88. https://doi.org/10.21423/bovine-vol50no1p65-88.

Toullec, R., J.-F. Frantzen, C.-M. Mathieu, Y. Lento, C. Marpillat, and C. Raynal. 1974. Influence de la coagulation des protéines du lait sur l'utilisation digestive d'un lait de remplacement par le veau préruminant. Ann. Zootech. 23:359-364. https://doi.org/10.1051/animres: 19740309.

Volcani, R., S. Gordin, Z. Nitsan, and A. Hasdai. 1971. Growth and nutrient utilization by calves fed milk replacers containing milk or soybean protein concentrate heated to various degrees. J. Dairy Sci. 54:1294-1299. https:// doi.org/10.3168/jds.S0022-0302(71)86023-X.

Wood, A. S., J. D. Donker, and J. B. Williams. 1970. Digestibility of dry matter and nitrogen and the nitrogen balance of three skim milk diets fed to Holstein calves. J. Dairy Sci. 53:221-226. https://doi.org/10.3168/jds.S0022 -0302(70)86183-5.

\section{Notes}

J. D. Quigley (1) https://orcid.org/0000-0001-8400-8963

T. S. Dennis () https://orcid.org/0000-0003-3424-5498

F. X. Suarez-Mena (ㄴ) https://orcid.org/0000-0002-1546-5893

T. M. Hill ๑ https://orcid.org/0000-0003-1304-5016

K. M. Aragona @ https://orcid.org/0000-0003-3674-838X

This research was wholly funded by Cargill Inc. The authors have not stated any conflicts of interest. 